\title{
Health Effects of Radon Exposure
}

\author{
Jin-Kyu Kang ${ }^{1,2}$, Songwon $\mathrm{Seo}^{3}$, and Young Woo $\operatorname{Jin}^{3}$ \\ ${ }^{1}$ Dongnam Radiation Emergency Medical Center, ${ }^{2}$ Department of Radiation Oncology, Dongnam Institute of Radiological \& Medical Sciences, \\ Busan; \\ ${ }^{3}$ National Radiation Emergency Medical Center, Korea Institute of Radiological \& Medical Sciences, Seoul, Korea.
}

\begin{abstract}
Radon is a naturally occurring radioactive material that is formed as the decay product of uranium and thorium, and is estimated to contribute to approximately half of the average annual natural background radiation. When inhaled, it damages the lungs during radioactive decay and affects the human body. Through many epidemiological studies regarding occupational exposure among miners and residential exposure among the general population, radon has been scientifically proven to cause lung cancer, and radon exposure is the second most common cause of lung cancer after cigarette smoking. However, it is unclear whether radon exposure causes diseases other than lung cancer. Media reports have often dealt with radon exposure in relation to health problems, although public attention has been limited to a one-off period. However, recently in Korea, social interest and concern about radon exposure and its health effects have increased greatly due to mass media reports of high concentrations of radon being released from various close-to-life products, such as mattresses and beauty masks. Accordingly, this review article is intended to provide comprehensive scientific information regarding the health effects of radon exposure.
\end{abstract}

Key Words: Radon, inhalation exposure, lung neoplasm

\section{INTRODUCTION}

Radon is a radioactive gas of natural origin that is formed as the decay product of uranium and thorium found in soil and rocks. As a naturally occurring radioactive material, radon is present everywhere in the air at various concentrations, and radon is estimated to contribute to approximately half of the average annual natural background radiation..$^{-3}$ There are about 40 known isotopes of radon, most of which have short half-lives in the microsecond to millisecond range and have little practical significance. Among them, radon-222 (radon) and radon-220 (thoron) are of practical significance. As the most abundant isotope of radon, radon-222 has a physical half-life of 3.823 days that comes from the decay of radium. Thoron has a phys-

Received: May 8, 2019 Revised: June 3, 2019

Accepted: June 6, 2019

Corresponding author: Young Woo Jin, MD, PhD, National Radiation Emergency Medical Center, Korea Institute of Radiological \& Medical Sciences, 75 Nowon-ro, Nowon-gu, Seoul 01812, Korea.

Tel: 82-2-3399-5800, Fax: 82-2-3399-5870, E-mail: ywjin@kirams.re.kr

-The authors have no potential conflicts of interest to disclose.

(C) Copyright: Yonsei University College of Medicine 2019

This is an Open Access article distributed under the terms of the Creative Commons Attribution Non-Commercial License (https://creativecommons.org/licenses/ by-nc/4.0) which permits unrestricted non-commercial use, distribution, and reproduction in any medium, provided the original work is properly cited. ical half-life of 55.6 seconds that comes from decay of thorium. Each of these isotopes undergoes radioactive decay with the emission of alpha particles that change them into different elements, so-called radon progeny. Radon and its progeny can enter the human body when inhaled or swallowed. Most of the inhaled radon is exhaled. However, a small amount of radon and its progeny may remain in the lungs, undergo radioactive decay, and emit alpha particles, leading to lung damage. ${ }^{4}$

In May 2018, there was a news report that radon gas is released from mattresses manufactured by a particular company in South Korea. The problematic mattresses contained monazite, a substance that releases radon gas. Since this news report, other reports of indiscriminate use of monazite in underwear, accessories, beauty masks, and building materials were released, which led to social concerns about the health effects of radon exposure. In this regard, this study will look at the health effects of radon exposure in humans.

\section{HISTORY OF THE RECOGNITION OF THE HEALTH EFFECTS OF RADON EXPOSURE}

In the sixteenth century, it was known that some miners in central Europe died in the primes of their life with pulmonary 
symptoms and rapidly progressing cachexia. ${ }^{5}$ In 1530 , Paracelsus, a Swiss physician, named this lung disease "mala metallorum" in his book. In 1556, Georg Agricola, a German scientist and mineralogist described mala metallorum as a wasting disease of miners and recommended frequent ventilation and maintenance of respiratory protection during their work to prevent mala metallorum in his textbook on mining titled "De Re Metallica." However, over the subsequent few hundred years, it remained unclear as to what mala metallorum was and what caused the disease.

In 1879, Harting and Hesse performed an autopsy on a miner who had died of mala metallorum and identified mala metallorum as lung cancer. ${ }^{6}$ Friedrich Ernst Dorn, a German physicist discovered a radioactive substance that was emitted from radium in 1900, later named radon. In 1924, Ludewig, et al. reported that high concentrations of radon in the air were detected at certain mines in Czechoslovakia, where there was a high incidence of lung cancer, which led to the hypothesis that radon exposure could cause lung cancer. ${ }^{7}$

Since the era of the "cold war" in the 1940s, when the "uranium rush" led to the supply of feed material for nuclear weapons production, many uranium mines have been developed all over the world, especially in Germany, Czech Republic, Cana$\mathrm{da}$, and the United States of America. Epidemiological studies of miners who worked in these uranium mines revealed that they were more likely to die of lung cancer than the general population. Since the 1950s, the recognition that radon and its progeny can accumulate at high concentrations in homes has led to concern about the potential lung cancer risk associated with domestic indoor exposure in the general population. As a result of this awareness, many epidemiological studies directly concerning the relationship between domestic indoor radon exposure and lung cancer in the general population have been published since the 1980s. Based primarily on studies of underground miners exposed to high levels of radon gas, radon was classified as a carcinogenic agent by the World Health Organization in 1986 and by the International Agency for Research on Cancer in 1988.

\section{HEALTH EFFECT OF RADON EXPOSURE: LUNG CANCER}

The relationship between radon exposure and lung cancer risk is described separately for occupational exposure among underground miners and residential exposure among the general population.

\section{Lung cancer risk in underground miners}

Since the 1960s, epidemiological studies of lung cancer risk in underground miners have been published. In studies of radon-exposed underground miners, radon progeny concentrations are generally expressed in terms of "working level (WL)" and "working level month (WLM)". WL is defined as any combination of short-lived radon progeny in $1 \mathrm{~L}$ of air that results in the ultimate release of $1.3 \times 10^{5} \mathrm{MeV}$ of potential energy from alpha particles. WLM is defined as the cumulative exposure of an individual at a concentration of $1 \mathrm{WL}$ for a working month of 170 hours. One WLM is approximately equivalent to the dose received by a person who lives for a year in a dwelling with a radon concentration of $227 \mathrm{~Bq} / \mathrm{m}^{3} .{ }^{8}$ Table 1 lists the representative studies of radon exposure and lung cancer risk in underground miners with occupational exposure. ${ }^{9-21}$

The first comprehensive study on the relationship between radon exposure and lung cancer risk in underground miners was the Biological Effects of Ionizing Radiations (BEIR) IV report, which included cohort studies of miners in Colorado, Ontario, Eldorado, and Malmberget. ${ }^{9}$ According to the BEIR IV report, the excess relative risk per $100 \mathrm{WLM}$ was 1.3 [95\% confidence interval (CI): 0.8-2.3]. Five years after the release of the BEIR IV report, the International Commission on Radiological Protection (ICRP) 65 report was published. Some of the epidemiological studies covered in the ICRP 65 report overlapped with those covered in the BEIR IV report (cohorts from Colorado, Ontario, Eldorado, and Malmberget), and some studies were added (from New Mexico, Bohemia, and France). The excessive relative risk per 100 WLM was 1.34 (95\% CI: 0.82-2.13), which was similar to the result of the BEIR IV report. ${ }^{10}$ In 1999 , the BEIR IV report was extended to include 11 cohort studies and more than 60000 miners, resulting in the BEIR VI report, which reported an excessive relative risk per $100 \mathrm{WLM}$ of 0.55 (95\% CI: 0.27-1.13). ${ }^{11}$ The BEIR VI report also considered the modifying factors of relative risk, such as time since exposure, attained age, and exposure rate. Miners exposed at a younger age and exposed to relatively low radon concentrations had a higher percentage increase in lung cancer death rate per WLM, compared to other miners. After the BEIR VI report, a more extensive and comprehensive study was described in the United Nations Scientific Committee on the Effects of Atomic Radiation (UNSCEAR) 2006 report. $^{12}$ According to the UNSCEAR 2006 report, the excess relative risk per $100 \mathrm{WLM}$ was 0.59 (95\% CI: 0.35-1.00). In the ICRP 115 report, the Commission recommended that the detriment-adjusted nominal risk coefficient of $5 \times 10^{-4}$ per WLM $\left(14 \times 10^{-5}\right.$ per $\left.\mathrm{mJh} / \mathrm{m}^{3}\right)$ should be used for radon- and radon-progeny-induced lung cancer, and this value was approximately twice the value calculated in the ICRP 65 report. Considering this finding, the recommended maximum reference level of indoor radon was lowered from 600 $\mathrm{Bq} / \mathrm{m}^{3}$ to $300 \mathrm{~Bq} / \mathrm{m}^{3}$, which corresponds to an annual effective dose of $4 \mathrm{mSv}$ at workplace and $14 \mathrm{mSv}$ at home. ${ }^{8}$

After these comprehensive studies, several updated or new cohort studies were published as shown in Table 1. In the near future, a new comprehensive report including these new studies is expected to be reported. 
Table 1. Radon Exposure and Lung Cancer Risk among Underground Miners with Occupational Exposure

\begin{tabular}{|c|c|c|c|c|c|c|}
\hline Country & Author & $\begin{array}{c}\text { Year of } \\
\text { publication }\end{array}$ & Sample size & $\begin{array}{l}\text { Person-years } \\
\text { of exposure }\end{array}$ & $\begin{array}{c}\text { No. of lung } \\
\text { cancers cases }\end{array}$ & $\begin{array}{l}\text { ERR/100 WLM } \\
\text { (95\% CI) }\end{array}$ \\
\hline \multirow[t]{5}{*}{ Combined study } & BEIR IV ${ }^{9}$ & 1988 & 22562 & 433019 & 459 & $1.3(0.8,2.3)$ \\
\hline & ICRP $65^{10}$ & 1993 & 31486 & 635022 & 1047 & $1.34(0.82,2.13)$ \\
\hline & BEIR VI ${ }^{11}$ & 1999 & 60606 & 888906 & 2674 & $0.55(0.27,1.13)$ \\
\hline & UNSCEAR $^{12}$ & 2009 & 128634 & 3246467 & 5715 & $0.59(0.35,1.00)$ \\
\hline & Lane, et al. ${ }^{13}$ & 2019 & $\begin{array}{l}\text { Low cumulative radon exposure } \\
\qquad 100 \mathrm{WLM}\end{array}$ & 394236 & 408 & $2.2(1.3,3.4)$ \\
\hline \multirow[t]{2}{*}{ Canada } & Keil, et al..$^{14}$ & 2015 & 4124 & 130000 & 617 & $1.17(1.15,1.17)$ \\
\hline & Navaranjan, et al. ${ }^{15}$ & 2016 & 28546 & 805650 & 1230 & $0.64(0.43,0.85)$ \\
\hline Czech Republic & Tomasek $^{16}$ & 2012 & 9978 & 308910 & 1141 & $0.97(0.74,1.27)$ \\
\hline \multirow[t]{2}{*}{ France } & Laborde-Castérot, et al. ${ }^{17}$ & 2014 & 5086 & 153063 & 159 & $0.53(0.19,1.07)$ \\
\hline & Rage, et al. ${ }^{18}$ & 2018 & 5400 & 186994 & 211 & $0.73(0.32,1.33)$ \\
\hline \multirow[t]{2}{*}{ Germany } & Walsh, et al. ${ }^{19}$ & 2010 & 58987 & 1997041 & 3016 & $0.20(0.17,0.22)$ \\
\hline & Kreuzer, et al. ${ }^{20}$ & 2015 & 5504 & 158383 & 159 & $3.39(-0.01,6.78)$ \\
\hline Sweden & Jonsson, et al. ${ }^{21}$ & 2010 & 5486 & 170204 & 122 & $2.20(0.23,3.77)$ \\
\hline
\end{tabular}

ERR, excess relative risk; WLM, working level month; Cl, confidence interval; BEIR, Biological Effects of lonizing Radiations; ICRP, International Commission on Radiological Protection; UNSCEAR, United Nations Scientific Committee on the Effects of Atomic Radiation.

\section{Lung cancer risk in the general population with residential exposure}

With the identification of an increased risk of lung cancer due to occupational radon exposure in miners, residential exposure in the general population is also be expected to yield an increased risk of lung cancer. However, it should be taken into account that there is a substantial uncertainty to directly extrapolate the results of the underground miners, since the special nature of the cohort of underground miners and the propensity of the cohort of the general population may differ in their smoking habits and exposure to other harmful substances, such as arsenic and quartz, which can also cause lung cancer.

Epidemiological studies regarding residential radon exposure and the risk of lung cancer in the general population usually use the average concentration of radon gas per cubic meter $\left(\mathrm{Bq} / \mathrm{m}^{3}\right.$ or $\mathrm{pCi} / \mathrm{L}$, where $1 \mathrm{pCi} / \mathrm{L}$ is equal to $37 \mathrm{~Bq} / \mathrm{m}^{3}$ ) of indoor air over the period of individual residence.

Table 2 shows the case-control studies that have reported on residential radon exposure and lung cancer risk..$^{22-29}$ While some of these studies have reported an increased risk of lung cancer in proportion to radon exposure dose, some studies did not report statistically significant results. The observation that many studies regarding residential exposure of the general population showed statistical insignificance, compared to occupational exposure among miners, could be explained by the smaller cohorts and the relatively lower levels of exposure to radon than among miners. Accordingly, several reports that collected single cohort studies and carried out combined analyses were published, and representative combined studies are shown in Table $3 .^{30-36}$ Most combined studies reported a statistically significant increase in lung cancer risk in proportion to radon exposure. Among them, in a collaborative study from 13 European case-control studies, the risk of lung cancer increased by $16 \%$ (95\% CI: 5-31) per $100 \mathrm{~Bq} / \mathrm{m}^{3}$ after correction for random uncertainties in measuring radon concentrations. The absolute risk of lung cancer by age 75 years at usual radon concentrations of 0,100 , and $400 \mathrm{~Bq} / \mathrm{m}^{3}$ would be about $0.4 \%$, $0.5 \%$, and $0.7 \%$, respectively for lifelong non-smokers and about 25 times greater $(10 \%, 12 \%$, and $16 \%)$ for cigarette smokers. That study also concluded that the dose-response relation seemed to be linear, with no threshold dose, and there was a significant dose-response relation even at low doses. ${ }^{34}$

Considering the epidemiologic studies regarding the relationship between radon exposure and lung cancer risk so far, the majority of studies of underground miners and most combined studies of the general population have reported that the risk of lung cancer increases statistically significantly in proportion to radon exposure. The World Health Organization considers that radon exposure is the second most common cause of lung cancer after cigarette smoking. ${ }^{37}$ Moreover, since even low concentrations of radon exposure can also result in a small increase in the risk of lung cancer, a national radon policy is needed to reduce the risk of lung cancer and raise public awareness.

\section{HEALTH EFFECTS OF RADON: DISEASES OTHER THAN LUNG CANCER}

There are many pieces of scientific evidence indicating that radon exposure can cause lung cancer; however, it is unclear whether radon can cause diseases other than lung cancer. Due to the unique biokinetics of radon inhalation in the body, the effective radiation doses reaching specific organs are much lower than that received by the lungs. ${ }^{38}$ Since radon mainly affects the human body by releasing alpha particles, it hardly 
causes health problems by external exposure. Therefore, when assessing a possible association between radon exposure and diseases other than lung cancer, the rationale for such a relationship is weak.

Many studies regarding the relationship between radon exposure and hematological cancers have been reported, and these studies are shown in Table $4 .{ }^{39-48}$ Although some studies have suggested that radon may cause leukemia, many other studies did not show statistical significance. Some studies ${ }^{39,44}$ even reported negative correlations; thus, the opinion that radon exposure may cause leukemia is generally not accepted as a scientific fact. However, it is thought that a combined report

Table 2. Case-Control Studies Regarding the Relationship between Residential Radon Exposure and Lung Cancer Risk

\begin{tabular}{|c|c|c|c|c|c|c|}
\hline Country & Author & $\begin{array}{c}\text { Year of } \\
\text { publication }\end{array}$ & Study design & $\begin{array}{c}\text { Sample size } \\
\text { (Case/Control) }\end{array}$ & $\begin{array}{l}\text { Grouping } \\
\left(\mathrm{Bq} / \mathrm{m}^{3}\right)\end{array}$ & $\begin{array}{l}\text { Risk estimate } \\
\quad(95 \% \mathrm{CI})\end{array}$ \\
\hline China & Wang, et al..$^{22}$ & 2002 & Case-control & $768 / 1659$ & 100 & $\begin{array}{c}\text { OR } \\
1.19(1.05,1.47)\end{array}$ \\
\hline Czech Republic & Tomasek $^{23}$ & 2013 & $\begin{array}{l}\text { Case-control } \\
\text { Never smoker } \\
\text { Ever smoker }\end{array}$ & $\begin{array}{c}370 / 1399 \\
58 / 670 \\
312 / 729\end{array}$ & 100 & $\begin{array}{c}\text { ERR } \\
0.14(0.03,0.39)^{*} \\
0.73(0.02,1.90)^{*} \\
0.14(0.02,0.30)^{*}\end{array}$ \\
\hline France & Baysson, et al. ${ }^{24}$ & 2004 & Case-control & 486/984 & 100 & $\begin{array}{c}\text { ERR } \\
0.04(-0.01,0.11)\end{array}$ \\
\hline \multirow[t]{2}{*}{ Spain } & Barros-Dios, et al. ${ }^{25}$ & 2012 & Case-control & $349 / 513$ & $\begin{array}{c}<50 \\
50-00 \\
101-147 \\
>147\end{array}$ & $\begin{array}{c}\mathrm{OR} \\
1.00 \\
1.87(1.21,2.88) \\
2.25(1.32,3.84) \\
2.21(1.33,3.69)\end{array}$ \\
\hline & Torres-Durán, et al. ${ }^{26}$ & 2014 & $\begin{array}{l}\text { Case-control } \\
\text { Never smoker }\end{array}$ & $192 / 329$ & $\begin{array}{c}\leq 100 \\
101-147 \\
148-199 \\
\geq 200\end{array}$ & $\begin{array}{c}\text { OR } \\
1.00 \\
0.80(0.43,1.50) \\
1.16(0.64,2.11) \\
2.42(1.45,4.06)\end{array}$ \\
\hline UK & Darby, et al. ${ }^{27}$ & 1998 & Case-control & $982 / 3185$ & 100 & $\begin{array}{c}\text { ERR } \\
0.12(-0.05,0.33)\end{array}$ \\
\hline \multirow[t]{2}{*}{ USA } & Sandler, et al. ${ }^{28}$ & 2006 & Case-control & $1474 / 1811$ & 100 & $\begin{array}{c}\text { ERR } \\
0.002(-0.21,0.21)\end{array}$ \\
\hline & Wilcox, et al. ${ }^{29}$ & 2008 & Case-control & $651 / 740$ & 100 & $\begin{array}{c}\mathrm{OR} \\
1.05(0.86,1.56)\end{array}$ \\
\hline
\end{tabular}

Cl, confidence interval; OR, odds ratio; ERR, excess relative risk; UK, United Kingdom; USA, United States of America.

${ }^{*} 90 \%$ confidence interval.

Table 3. Pooled Studies Regarding Residential Radon Exposure and Lung Cancer Risk

\begin{tabular}{|c|c|c|c|c|c|}
\hline Author & Year of publication & No. of studies & Sample size (Case/Control) & Grouping $\left(\mathrm{Bq} / \mathrm{m}^{3}\right)$ & Risk estimate $(95 \% \mathrm{CI})$ \\
\hline Lubin, et al. ${ }^{30}$ & 1997 & 8 & $4263 / 6612$ & 150 & ERR $0.14(0.0,0.3)$ \\
\hline Pavia, et al. ${ }^{31}$ & 2003 & 17 & NR & $\begin{array}{r}50 \\
100 \\
150 \\
200 \\
250\end{array}$ & $\begin{array}{l}\text { Adjusted OR } \\
1.07(1.04-1.11) \\
1.15(1.07-1.24) \\
1.24(1.11-1.38) \\
1.33(1.15-1.354) \\
1.43(1.19-1.72)\end{array}$ \\
\hline Lubin, et al. ${ }^{32}$ & 2004 & 2 & 1050/1996 & 100 & OR $1.33(1.01,1.36)$ \\
\hline Krewski, et al. ${ }^{33}$ & 2005 & 7 & $3662 / 4966$ & 100 & OR $1.11(1.00,1.28)$ \\
\hline Darby, et al. ${ }^{34}$ & 2006 & 13 & 7148/14208 & 100 & ERR $0.08(0.03,0.16)$ \\
\hline Zhang, et al. ${ }^{35}$ & 2012 & 22 & $13380 / 21102$ & 100 & ERR $0.07(0.04,0.10)$ \\
\hline Lorenzo-González, et al. ${ }^{36}$ & 2019 & Never smokers in Spain & $523 / 892$ & $\begin{array}{c}\leq 100 \\
101-147 \\
148-199 \\
\geq 200\end{array}$ & $\begin{array}{c}\mathrm{OR} \\
1.00 \\
1.14(0.80,1.64) \\
1.25(0.85,1.85) \\
1.73(1.27,2.35)\end{array}$ \\
\hline
\end{tabular}

Cl, confidence interval; ERR, excess relative risk; NR, not reported; OR, odds ratio. 
Table 4. Epidemiologic Studies Regarding the Relationship between Radon Exposure and Hematologic Cancer Risk

\begin{tabular}{|c|c|c|c|c|c|c|}
\hline Country & Author & $\begin{array}{c}\text { Year } \\
\text { of publication }\end{array}$ & Type of leukemia & $\begin{array}{c}\text { Sample size } \\
\text { (Case/Control) }\end{array}$ & $\begin{array}{l}\text { Grouping } \\
\left(\mathrm{Bq} / \mathrm{m}^{3}\right)\end{array}$ & $\begin{array}{l}\text { Risk estimate } \\
(95 \% \mathrm{Cl})\end{array}$ \\
\hline Sweden & Stjernfeldt, et al..$^{39}$ & 1987 & ALL, AML & $7 / 7$ & - & $\begin{array}{l}\text { Case } 156 \mathrm{~Bq} / \mathrm{m}^{3} \\
\text { Control } 333 \mathrm{~Bq} / \mathrm{m}^{3}\end{array}$ \\
\hline USA & Lubin, et al. ${ }^{40}$ & 1998 & ALL & $\begin{array}{c}\text { 281/281 (matched) } \\
\text { 505/443 (unmatched) }\end{array}$ & $>148$ vs. $<37$ & $\begin{array}{l}\text { ERR: } 0.02(-0.5,1.0) \\
\text { ERR: } 0.44(-0.1,1.3)\end{array}$ \\
\hline Germany & Kaletsch, et al. ${ }^{41}$ & 1999 & Acute leukemias & $82 / 209$ & $>70$ vs. $<70$ & OR $1.30(0.32,5.33)$ \\
\hline Canada and USA & Steinbuch, et al ${ }^{42}$ & 1999 & AML & $173 / 254$ & $>100$ vs. $<37$ & OR $1.1(0.6,2.0)$ \\
\hline UK & Law, et al. ${ }^{43}$ & 2000 & Acute leukemias & $578 / 983$ & $>200$ vs. $<25$ & OR $0.90(0.31,2.62)$ \\
\hline UK & $\begin{array}{l}\text { UK Childhood Cancer Study } \\
\text { Investigators }{ }^{44}\end{array}$ & 2002 & $\begin{array}{c}\text { ALL } \\
\text { Other leukemias }\end{array}$ & $\begin{array}{l}805 / 1306 \\
146 / 232\end{array}$ & $>30$ vs. $<8$ & $\begin{array}{l}\text { OR: } 0.77(0.61,0.99) \\
\text { OR: } 0.71(0.43,1.19\end{array}$ \\
\hline Denmark & Raaschou-Nielsen ${ }^{45}$ & 2008 & $\begin{array}{c}\text { ALL } \\
\text { ANLL } \\
\text { Chronic leukemias }\end{array}$ & $\begin{array}{l}860 / 1720 \\
150 / 300 \\
143 / 286\end{array}$ & $\begin{array}{c}>178 \text { vs. }<52 \\
\text { (for } 5 \text { yr-old child) }\end{array}$ & $\begin{array}{c}\text { ERR: } 0.63(0.05,1.53) \\
\text { ERR: }-0.40(-0.75,0.41) \\
\text { ERR: } 0.36(-0.52,2.83)\end{array}$ \\
\hline Switzerland & Hauri, et al. ${ }^{46}$ & 2013 & $\begin{array}{l}\text { All leukemias } \\
\text { ALL }\end{array}$ & $\begin{array}{l}283 \text { (cohort) } \\
225 \text { (cohort) }\end{array}$ & $\geq 139.9$ vs. $<77.7$ & $\begin{array}{l}\text { HR: } 0.95(0.63,1.43) \\
\text { HR: } 0.90(0.56,1.43)\end{array}$ \\
\hline Norway & Del Risco Kollerud, et al. ${ }^{47}$ & 2014 & All leukemias & 431 (cohort) & $\begin{array}{c}<50 \\
50-100 \\
>100 \\
\text { Per } 100\end{array}$ & $\begin{array}{c}H R 1.00 \\
1.05(0.82,1.33) \\
1.06(0.82,1.39) \\
0.99(0.86,1.13)\end{array}$ \\
\hline USA & Teras, et al. ${ }^{48}$ & 2016 & $\begin{array}{l}\text { All hematologic } \\
\text { cancers }\end{array}$ & $\begin{array}{c}1308 \\
\text { (women's cohort) }\end{array}$ & $\begin{array}{c}<74 \\
74-<100 \\
100-124 \\
125-148 \\
>148 \\
\text { Per } 100\end{array}$ & $\begin{array}{c}\text { HR 1.00 } \\
0.97(0.78,1.21) \\
1.37(1.07,1.75) \\
1.39(0.96,2.02) \\
1.63(1.23,2.18) \\
1.38(1.15,1.65)\end{array}$ \\
\hline
\end{tabular}

Cl, confidence interval; ALL, acute lymphoblastic leukemia; AML, acute myeloid leukemia; USA, United States of America; ERR, excess relative risk; OR, odds ratio; UK, United Kingdom; ANLL, acute nonlymphocytic leukemia; HR, hazard ratio.

of all case-control studies will be needed.

According to the Cancer Prevention Study II, which was a prospective trial conducted in the United States of America, radon exposure was significantly associated with chronic obstructive pulmonary disease (COPD) mortality (hazard ratio per $100 \mathrm{~Bq} / \mathrm{m}^{3}, 1.13$; 95\% CI: 1.05-1.21), suggesting that residential radon exposure may increase the mortality rate due to COPD ${ }^{49}$ More studies regarding the relationship between radon exposure and benign lung disease are thought to be needed.

The relationship between radon exposure and central nervous system tumors is also inconclusive. According to a systematic review performed by Ruano-Ravina et al., ${ }^{50}$ among 18 studies, some studies showed an association with radon and cancers of the central nervous system, while the majority did not show any effect. The relationship between radon exposure and thyroid cancer, ${ }^{51,52}$ skin cancer, ${ }^{33-55}$ head and neck cancer, ${ }^{56-58}$ stomach cancer $;{ }^{59}$ heart disease; ${ }^{60}$ and reproductive, fetal, and hereditary effects ${ }^{61}$ have also not been scientifically proven for the same reason.

\section{DISCUSSION AND CONCLUSION}

It has been scientifically proven that exposure to radon can cause lung cancer. Diseases other than lung cancer, however, seem to be unrelated, and the relationship with some diseases, especially leukemia and COPD, remains controversial. Nevertheless, as interest among the public increases in the event of nuclear or radiation-related issues and causes excessive concern, passing on scientifically unproven information recklessly to the general public will lead to its acceptance as the truth, regardless of its authenticity. Therefore, mass media and related experts need to deliver accurate information continuously to the general public based on scientific evidence. When mass media or related experts communicate information to the public, there is a need for a balanced view supported by many studies, rather than focusing on one or two studies.

There have been many commercial advertisements recently for air purifiers, foods, and drugs that can remove radon from the air or the body. For now, scientific evidence regarding their health effects is insufficient, and these should be elucidated clearly. Based on the misunderstanding that anions can have a beneficial health effect, a monazite-containing substance that could release anions was added to bed mattresses, and this resulted in the radon bed mattress incident in Korea. Thus, if products that are scientifically not validated are sold commercially through false or exaggerated advertisements, consumers could be deceived twice. Hence, attempts to further spread 
public fear of radon for commercial purposes and economic gains should be eradicated.

It is difficult to accurately assess by how much the risk of lung cancer would increase among customers who used radon-releasing mattresses based only on the report regarding the concentration of radon in a specific mattress model announced by the Korean government. Furthermore, because the occurrence of lung cancer due to radon exposure is a stochastic effect, this would need to be observed through long-term follow-up (for several years to several decades). Some experts argue for epidemiological investigations regarding the radon mattress incident; however, in order to carry out an accurate epidemiological study, more precise individual data (e.g., duration of radonreleasing bed mattress use, sleeping habits, and sleep posture) need to be collected.

In conclusion, it is scientifically proven that radon exposure can cause lung cancer, whereas its relation with diseases other than lung cancer remains controversial. Mass media and related experts need to communicate accurate information to the general public, and it is necessary to maintain a balanced view supported by many studies when providing information to the general public.

\section{ACKNOWLEDGEMENTS}

This work was supported by the Nuclear Safety Research Program through the Korea Foundation Of Nuclear Safety (KoFONS) using financial resources granted by the Nuclear Safety and Security Commission (NSSC) of the Republic of Korea (no. 1802019).

\section{AUTHOR CONTRIBUTIONS}

Conceptualization: YW Jin and JK Kang. Acquisition of data: JK Kang, S Seo. Writing and review of manuscript: All authors. Study supervision: YW Jin. Manuscript approval: All authors.

\section{ORCID iDs}

Jin-Kyu Kang Songwon Seo Young Woo Jin https://orcid.org/0000-0003-4398-1788 https://orcid.org/0000-0001-6200-5120 https://orcid.org/0000-0002-0029-9028

\section{REFERENCES}

1. United Nations Scientific Committee on the Effects of Atomic Radiation. Sources and effects of ionizing radiation: effects. Vol. 2. New York (NY): United Nations; 2000.

2. National Research Council. Health risks from exposure to low levels of ionizing radiation: BEIR VII Phase 2. Vol. 7. Washington DC (WA): National Academies Press; 2006.

3. Bhaskaran R, Damodaran RC, Kumar VA, Panakal John J, Bangaru D, Natarajan C, et al. Inhalation dose and source term studies in a tribal area of Wayanad, Kerala, India. J Environ Public Health 2017; 2017:1930787.

4. Meenakshi C, Sivasubramanian K, Venkatraman B. Nucleoplasmic bridges as a biomarker of DNA damage exposed to radon. Mutat
Res 2017;814:22-8.

5. Pirchan A, Šikl H. Cancer of the lung in the miners of Jachymov (Joachimstal): report of cases observed in 1929-1930. Am J Cancer 1932;16:681-722.

6. Harting FH, Hesse W. Lung cancer, the mountain sickness in the Schneeberger pits. Viertelj Gerichtl Med Off Sanitäts 1879;30:296309 and 31, 102-32, 313-37.

7. Jacobi W. The history of the radon problem in mines and homes. Ann ICRP 1993;23:39-45.

8. Tirmarche M, Harrison JD, Laurier D, Paquet F, Blanchardon E, Marsh JW, et al. ICRP Publication 115. Lung cancer risk from radon and progeny and statement on radon. Ann ICRP 2010;40:1-64.

9. National Research Council. Health risks of radon and other internally deposited alpha-emitters: BEIR IV. Vol. 4. Washington DC (WA): National Academies Press; 1988.

10. ICRP. Protection against radon-222 at home and at work. Pergamon, Oxford: International Commission on Radiological Protection (ICRP) Publication 65; 1993.

11. National Research Council. Health effects of exposure to radon: BEIR VI. Vol. 6. Washington DC (WA): National Academies Press; 1999.

12. United Nations Scientific Committee on the Effects of Atomic Radiation. Effects of ionizing radiation: scientific annexes $\mathrm{C}, \mathrm{D}$, and E. Vol 2. New York (NY): United Nations; 2009.

13. Lane RSD, Tomášek L, Zablotska LB, Rage E, Momoli F, Little J. Low radon exposures and lung cancer risk: joint analysis of the Czech, French, and Beaverlodge cohorts of uranium miners. Int Arch Occup Environ Health 2019;92:747-62.

14. Keil AP, Richardson DB, Troester MA. Healthy worker survivor bias in the Colorado Plateau uranium miners cohort. Am J Epidemiol 2015;181:762-70.

15. Navaranjan G, Berriault C, Do M, Villeneuve PJ, Demers PA. Cancer incidence and mortality from exposure to radon progeny among Ontario uranium miners. Occup Environ Med 2016;73:838-45.

16. Tomasek L. Lung cancer mortality among Czech uranium miners-60 years since exposure. J Radiol Prot 2012;32:301-14.

17. Laborde-Castérot H, Laurier D, Caër-Lorho S, Etard C, Acker A, Rage E. Chest X-ray screening examinations among French uranium miners: exposure estimation and impact on radon-associated lung cancer risk. Occup Environ Med 2014;71:611-8.

18. Rage E, Caër-Lorho S, Laurier D. Low radon exposure and mortality among Jouac uranium miners: an update of the French cohort (1946-2007). J Radiol Prot 2018;38:92-108.

19. Walsh L, Dufey F, Tschense A, Schnelzer M, Grosche B, Kreuzer M. Radon and the risk of cancer mortality--internal Poisson models for the German uranium miners cohort. Health Phys 2010;99:292300.

20. Kreuzer M, Dufey F, Laurier D, Nowak D, Marsh JW, Schnelzer M, et al. Mortality from internal and external radiation exposure in a cohort of male German uranium millers, 1946-2008. Int Arch Occup Environ Health 2015;88:431-41.

21. Jonsson H, Bergdahl IA, Akerblom G, Eriksson K, Andersson K, Kågström L, et al. Lung cancer risk and radon exposure in a cohort of iron ore miners in Malmberget, Sweden. Occup Environ Med 2010;67:519-25

22. Wang Z, Lubin JH, Wang L, Zhang S, Boice JD Jr, Cui H, et al. Residential radon and lung cancer risk in a high-exposure area of Gansu Province, China. Am J Epidemiol 2002;155:554-64.

23. Tomasek L. Lung cancer risk from occupational and environmental radon and role of smoking in two Czech nested case-control studies. Int J Environ Res Public Health 2013;10:963-79.

24. Baysson H, Tirmarche M, Tymen G, Gouva S, Caillaud D, Artus JC, et al. Indoor radon and lung cancer in France. Epidemiology 2004;15:709-16

25. Barros-Dios JM, Ruano-Ravina A, Pérez-Ríos M, Castro-Bernárdez 
M, Abal-Arca J, Tojo-Castro M. Residential radon exposure, histologic types, and lung cancer risk. A case-control study in Galicia, Spain. Cancer Epidemiol Biomarkers Prev 2012;21:951-8.

26. Torres-Durán M, Ruano-Ravina A, Parente-Lamelas I, LeiroFernández V, Abal-Arca J, Montero-Martínez C, et al. Lung cancer in never-smokers: a case-control study in a radon-prone area (Galicia, Spain). Eur Respir J 2014;44:994-1001.

27. Darby S, Whitley E, Silcocks P, Thakrar B, Green M, Lomas P, et al. Risk of lung cancer associated with residential radon exposure in south-west England: a case-control study. Br J Cancer 1998;78:394408.

28. Sandler DP, Weinberg CR, Shore DL, Archer VE, Stone MB, Lyon $\mathrm{JL}$, et al. Indoor radon and lung cancer risk in connecticut and utah. J Toxicol Environ Health A 2006;69:633-54.

29. Wilcox HB, Al-Zoughool M, Garner MJ, Jiang H, Klotz JB, Krewski D, et al. Case-control study of radon and lung cancer in New Jersey. Radiat Prot Dosimetry 2008;128:169-79.

30. Lubin JH, Boice JD Jr. Lung cancer risk from residential radon: meta-analysis of eight epidemiologic studies. J Natl Cancer Inst 1997;89:49-57.

31. Pavia M, Bianco A, Pileggi C, Angelillo IF. Meta-analysis of residential exposure to radon gas and lung cancer. Bull World Health Organ 2003;81:732-8.

32. Lubin JH, Wang ZY, Boice JD Jr, Xu ZY, Blot WJ, De Wang L, et al. Risk of lung cancer and residential radon in China: pooled results of two studies. Int J Cancer 2004;109:132-7.

33. Krewski D, Lubin JH, Zielinski JM, Alavanja M, Catalan VS, Field RW, et al. Residential radon and risk of lung cancer: a combined analysis of 7 North American case-control studies. Epidemiology 2005;16:137-45.

34. Darby S, Hill D, Deo H, Auvinen A, Barros-Dios JM, Baysson H, et al. Residential radon and lung cancer--detailed results of a collaborative analysis of individual data on 7148 persons with lung cancer and 14,208 persons without lung cancer from 13 epidemiologic studies in Europe. Scand J Work Environ Health 2006;32 Suppl 1:1-83.

35. Zhang ZL, Sun J, Dong JY, Tian HL, Xue L, Qin LQ, et al. Residential radon and lung cancer risk: an updated meta- analysis of casecontrol studies. Asian Pac J Cancer Prev 2012;13:2459-65.

36. Lorenzo-González M, Ruano-Ravina A, Torres-Durán M, Kelsey KT, Provencio M, Parente-Lamelas I, et al. Lung cancer and residential radon in never-smokers: a pooling study in the Northwest of Spain. Environ Res 2019;172:713-8.

37. World Health Organization. WHO handbook on indoor radon: a public health perspective. Geneva: World Health Organization; 2009.

38. Kendall GM, Smith TJ. Doses to organs and tissues from radon and its decay products. J Radiol Prot 2002;22:389-406.

39. Stjernfeldt M, Samuelsson L, Ludvigsson J. Radiation in dwellings and cancer in children. Pediatr Hematol Oncol 1987;4:55-61.

40. Lubin JH, Linet MS, Boice JD Jr, Buckley J, Conrath SM, Hatch EE, et al. Case-control study of childhood acute lymphoblastic leukemia and residential radon exposure. J Natl Cancer Inst 1998;90:294300.

41. Kaletsch U, Kaatsch P, Meinert R, Schüz J, Czarwinski R, Michaelis J. Childhood cancer and residential radon exposure-results of a population-based case-control study in Lower Saxony (Germany). Radiat Environ Biophys 1999;38:211-5.

42. Steinbuch M, Weinberg CR, Buckley JD, Robison LL, Sandler DP. Indoor residential radon exposure and risk of childhood acute myeloid leukaemia. Br J Cancer 1999;81:900-6.

43. Law GR, Kane EV, Roman E, Smith A, Cartwright R. Residential radon exposure and adult acute leukaemia. Lancet 2000;355:1888.

44. UK Childhood Cancer Study Investigators. The United Kingdom Childhood Cancer Study of exposure to domestic sources of ionising radiation: 1: radon gas. Br J Cancer 2002;86:1721-6.

45. Raaschou-Nielsen O. Indoor radon and childhood leukaemia. Radiat Prot Dosimetry 2008;132:175-81.

46. Hauri D, Spycher B, Huss A, Zimmermann F, Grotzer M, von der Weid N, et al. Domestic radon exposure and risk of childhood cancer: a prospective census-based cohort study. Environ Health Perspect 2013;121:1239-44.

47. Del Risco Kollerud R, Blaasaas KG, Claussen B. Risk of leukaemia or cancer in the central nervous system among children living in an area with high indoor radon concentrations: results from a cohort study in Norway. Br J Cancer 2014;111:1413-20.

48. Teras LR, Diver WR, Turner MC, Krewski D, Sahar L, Ward E, et al. Residential radon exposure and risk of incident hematologic malignancies in the Cancer Prevention Study-II Nutrition Cohort. Environ Res 2016;148:46-54.

49. Turner MC, Krewski D, Chen Y, Pope CA 3rd, Gapstur SM, Thun MJ. Radon and COPD mortality in the American Cancer Society Cohort. Eur Respir J 2012;39:1113-9.

50. Ruano-Ravina A, Dacosta-Urbieta A, Barros-Dios JM, Kelsey KT. Radon exposure and tumors of the central nervous system. Gac Sanit 2018;32:567-75.

51. Goyal N, Camacho F, Mangano J, Goldenberg D. Evaluating for a geospatial relationship between radon levels and thyroid cancer in Pennsylvania. Laryngoscope 2015;125:E45-9.

52. Oakland C, Meliker JR. County-level radon and incidence of female thyroid cancer in Iowa, New Jersey, and Wisconsin, USA. Toxics 2018;6. pii: E17.

53. Wheeler BW, Allen J, Depledge MH, Curnow A. Radon and skin cancer in southwest England: an ecologic study. Epidemiology 2012;23:44-52.

54. Bräuner EV, Loft S, Sørensen M, Jensen A, Andersen CE, Ulbak K, et al. Residential radon exposure and skin cancer incidence in a prospective Danish cohort. PLoS One 2015;10:e0135642.

55. Vienneau D, de Hoogh K, Hauri D, Vicedo-Cabrera AM, Schindler C, Huss A, et al. Effects of radon and UV exposure on skin cancer mortality in Switzerland. Environ Health Perspect 2017;125: 067009.

56. Möhner M, Lindtner M, Otten H. Ionizing radiation and risk of laryngeal cancer among German uranium miners. Health Phys 2008; 95:725-33.

57. Kulich M, Reřicha V, Reřicha R, Shore DL, Sandler DP. Incidence of non-lung solid cancers in Czech uranium miners: a case-cohort study. Environ Res 2011;111:400-5.

58. Salgado-Espinosa T, Barros-Dios JM, Ruano-Ravina A. Radon exposure and oropharyngeal cancer risk. Cancer Lett 2015;369:45-9.

59. Auvinen A, Salonen L, Pekkanen J, Pukkala E, Ilus T, Kurttio P. Radon and other natural radionuclides in drinking water and risk of stomach cancer: a case-cohort study in Finland. Int J Cancer 2005; 114:109-13.

60. Villeneuve PJ, Lane RS, Morrison HI. Coronary heart disease mortality and radon exposure in the Newfoundland fluorspar miners' cohort, 1950-2001. Radiat Environ Biophys 2007;46:291-6.

61. Keith S, Doyle JR, Harper C, Mumtaz M, Tarrago O, Wohlers DW, et al. Toxicological profile for radon. Atlanta (GA): Agency for Toxic Substances and Disease Registry (US); 2012. 